\title{
A tüdö extravaszkuláris víztartalmának noninvazív vizsgálata és jelentősége szívelégtelenségben: a B-vonalak
}

\author{
Ágoston Gergely', Jambrik Zoltán ${ }^{2,3}$
}

\author{
1Szegedi Tudományegyetem, Általános Orvostudományi Kar, Családorvosi Intézet, Szeged \\ ${ }^{2}$ Semmelweis Egyetem, Városmajori Szív- és Érgyógyászati Klinika, Budapest \\ ${ }^{3}$ Békés Megyei Pándy Kálmán Kórház, Gyula
}

Levelezési cím: Dr. Ágoston Gergely, Szegedi Tudományegyetem, Általános Orvostudományi Kar, Családorvosi Intézet, Szeged, 6720 Szeged, Tisza Lajos krt. 109. Szeged, E-mail: agosoton.gergely@med.u-szeged.hu

\begin{abstract}
A pulmonalis pangás gyakori patofiziológiai folyamat szívelégtelenségben. Diagnosztizálása nagy jelentőséggel bír a betegek kezelése és prognózisa szempontjából. Sokáig úgy vélték, hogy légtartalma miatt az ultrahang alkalmatlan vizsgálóeljárás a tüdő feltérképezésére, később azonban felismerték, hogy a folyadékfelszaporodás következtében a tüdőparenchyma vizsgálhatóvá válik. A pulmonalis pangás konvencionális mellkas-röntgenfelvételen részben a Kerley B-vonalak képében jelenik meg, ezért a jelenség manifesztációjának gondolt mellkasi ultrahang-artefaktumokat is B-vonalaknak nevezzük. Egyszerü kardiális transzducerrel is vizualizálhatóak a légzőmozgásokkal szinkron változó, a pleura felületéről kiinduló és a tüdőparenchyma felé irányuló üstökösszerū, vertikális nyalábok. Az extravaszkuláris víztartalom noninvazív vizsgálata ultrahangkészülékkel, a B-vonalak számának feltérképezésével lehetséges. Az eljárás megfelelő szenzitivitással és specificitással képes kimutatni a heveny és a szubklinikus pangást. A B-vonalak nemcsak a diagnózis felállitásában segítenek, hanem hasznosak a szívelégtelen betegek terápiájának irányításában és a prognózis meghatározásában. A tüdő ultrahangozása kiváló diagnosztikus lehetőség a kardiológus kezében, mivel könnyen elsajátítható, betegágy mellett alkalmazható, sugárzásmentes, költséghatékony, korlátlanul ismételhető módszerröl van szó, amely noninvazív módon képes kimutatni a pulmonalis pangást.
\end{abstract}

Kulcsszavak: ultrahang, tüdő, pangás, szívelégtelenség

Non-invasive assessment and clinical importance of the extravascular lung water in heart failure: the B-lines Pulmonary congestion is a common and important pathophysiological finding in heart failure. It has a key feature in the management and prognosis of patients with heart failure. The lung parenchyma examination has been traditionally considered limited for ultrasound techniques due to the fact that ultrasound energy is rapidly dissipated in air. However, the presence of water in the lungs opens up the pulmonary acoustic window and allows to examine the lung parenchyma. B-lines may be more familiar for radiologists, known as radiological Kerley B-lines, a sign of extravascular lung water on chest $\mathrm{X}$-ray. In pulmonary congestion the lung ultrasound shows B-lines, which are comet-like signals arising from a pleural line with a movement synchronized with respiration. The assessment of the number and spatial extent of B-lines on the antero-lateral chest wall is useful for the identification of subclinical and symptomatic congestion, with high sensitivity and excellent specificity. Lung ultrasound also provides useful information in the management and prognosis for patients with heart failure. Lung ultrasound is an excellent diagnostic opportunity for the cardiologist. It is feasible, radiation free, low cost, can be done at bedside and allows non-invasive detection, in real time of pulmonary congestion.

Keywords: ultrasound, lungs, congestion, heart failure 


\section{Bevezető}

A kisvérköri pangás jelentősége,

a B-vonalak fogalma és keletkezése

A kisvérköri pangás gyakori patofiziológiai eltérés szívelégtelenségben. Klasszikus megjelenési formája a heveny balszívfél-elégtelenség, amelyre a rapidan kialakuló alveoláris és interstitiális folyadékfelszaporodás jellemzö, súlyos légszomj és a csökkent alveoláris oxigenizáció tüneteinek kíséretében. A kisvérköri pangás hátterében legtöbbször csökkent balkamra-funkció és szignifikáns billentyübetegség igazolható, azonban megtartott bal kamra szisztolés funkció mellett is kialakulnak a pulmonalis pangás jelei. A kisvérköri pangást és a kapcsolódó tüneteket a tüdőben megjelenő extravaszkuláris folyadékretenció okozza. A tüdőben kialakuló folyadékfelszaporodás társulhat a beteg testsúlynövekedésével, azonban a testsúly növekedése nélkül is - úgynevezett redisztribúció során - manifesztálódhat, balszívfél-elégtelenség tüneteit eredményezve. Balszívfél-elégtelenségben a kisvérköri pangás krónikus formában is jelen van, sokszor a heveny dekompenzációs tüneteket megelőzve már diagnosztizálható. Tekintettel a kisvérköri pangás meghatározó patofiziológiai szerepére szívelégtelenségben, a folyadékfelszaporodás kimutatása és követése a terápiás döntések irányításában nélkülözhetetlen, és mivel a pulmonalis pangás akár napokkal, hetekkel megelőzheti a bal szívfél dekompenzációs tüneteinek kialakulását, az időben történő terápiás beavatkozással az állapotrosszabbodás, hospitalizáció elkerülhető.

A pulmonalis pangás diagnózisában a klasszikus diagnosztikus eljárások közé tartozik a fizikális vizsgálat, elsősorban a hallgatózás, amelynek szenzitivitása és specificitása alacsony. A mellkasröntgen- és CT-vizsgálat szintén alkalmas a pangás diagnózisának felállítására, azonban sugárterheléssel járnak és betegágy mellett nem ismételhetőek korlátlanul. A tüdő ultra- hangvizsgálata optimális eljárásnak bizonyul a pulmonalis pangás diagnózisában és követésében $(1,2)$. Egyszerüen elsajátítható, betegágy melletti, költséghatékony, sugárzásmentes, gyakran ismételhető vizsgálóeljárásról van szó. Az ultrahang gyorsan szétoszlik a levegőben, ezért nem tartották alkalmas vizsgálóeljárásnak a tüdőben lévő kórfolyamatok vizsgálatára, később azonban bizonyítást nyert, hogy amennyiben a tüdőben lévő levegőt folyadék, vagy esetleg más szövet, például kötőszövet szorítja ki, az ultrahang számára elérhetővé, azaz vizsgálhatóvá válik a tüdőparenchyma (1. ábra).

Szívelégtelenségben a pulmonalis pangás (főként az extravaszkuláris térben történő folyadék-akkumuláció) az úgynevezett B-vonalak formájában vizualizálható. A pleura echodenz, horizontális vonalként látható ultrahangvizsgálat során, a B-vonalak a pleura vonaláról kiinduló, a tüdőparenchyma felé irányuló üstökösszerủ nyalábok, amelyek a légzőmozgásokkal szinkron megjelennek és eltűnnek (2. ábra). A B-vonalakat legtöbbször a kardiológiai vizsgálathoz használt vizsgálófejjel vizsgáljuk, de alkalmas a lineáris (vaszkuláris) transzducer is. Normál tüdőkép esetén egyöntetű fekete ultrahangképet látunk, amennyiben pangás van, megjelennek a B-vonalak, kifejezett pangás esetén pedig teljesen fehér a tüdőkép, ez legtöbbször heveny balszívfél-elégtelenség során észlelhető (1. ábra).

A B-vonalak eredetének korábban a folyadék által okozott interlobularis szeptummegvastagodást feltételezték (ahogyan a radiológiailag megfigyelt Kerley $B$-vonalak esetében is), azonban in vitro és ex vivo modellek alapján a B-vonalak nemcsak az interlobularis szeptum megvastagodásából adódnak. Leggyakrabban a folyadék-levegő találkozási felületen jönnek létre, ahol a folyadékkal telt vagy összeesett alveolusok érintkeznek a megfelelő légtartalommal rendel-
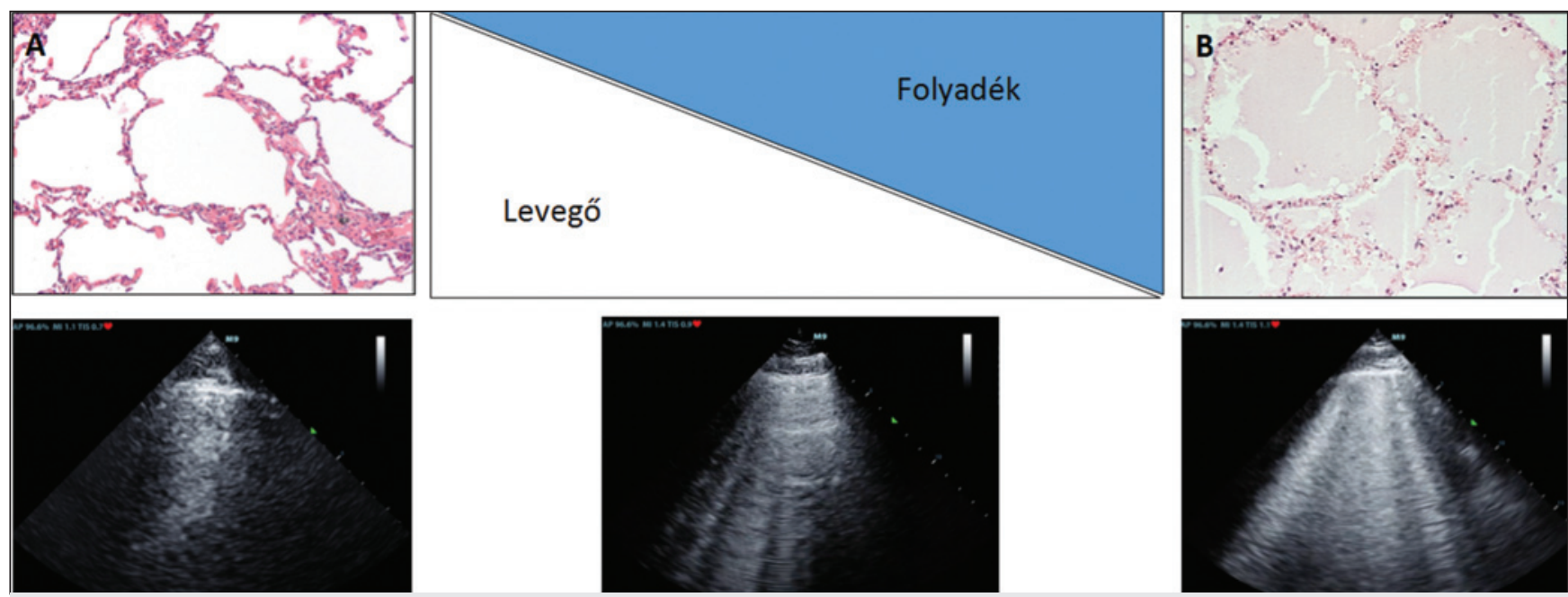

1. ÁBRA. A: A megfelelő légtartalmú, egészséges tüdőszövet ultrahangozása során B-vonalak nem láthatók. B: Amennyiben a tüdőben lévő levegőt folyadék szorítja ki, ultrahanggal a pangás diagnosztizálható, amely B-vonalak képében manifesztálódik. A szövettani metszetekért köszönettel tartozunk Iványi Béla professzor úrnak. 


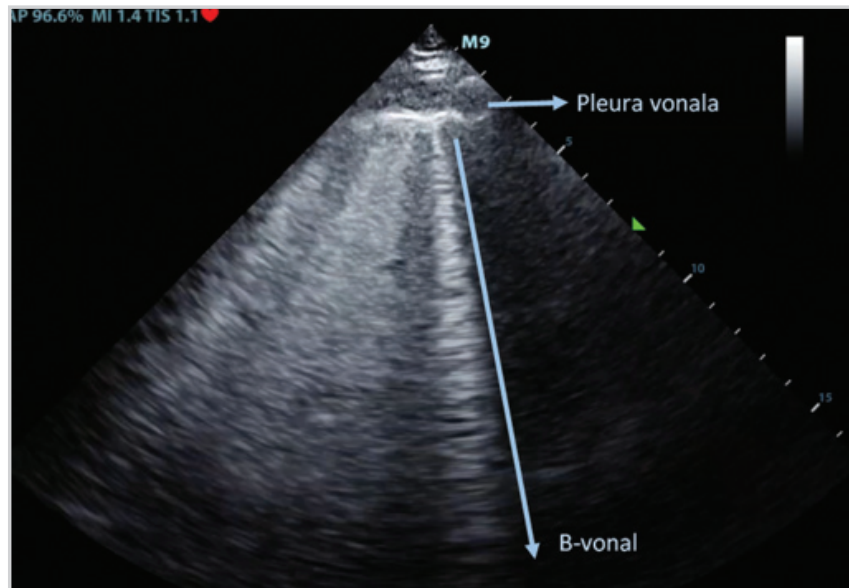

2. ÁBRA. A tüdő ultrahangvizsgálata során a B-vonalak megjelenése pangásra utal. Ezek a pleura síkjából kiinduló, a tüdő szövete felé irányuló üstökösszerű nyalábok, amelyek a légzőmozgással szinkron megjelennek és eltűnnek

kező alveolusokkal $(3,4)$. A B-vonalak száma annál több, minél nagyobb tüdőtérfogatban telnek meg folyadékkal az alveolusok, azaz minél kifejezettebb az extravaszkuláris folyadékfelszaporodás. Ismert patofiziológiai folyamat, hogy balszívfél-elégtelenségben a bal kamrai végdiasztolés nyomás emelkedése okozza az alveolusokban és az interstitialis térben a folyadékfelszaporodást. Balszívfél-elégtelenségben a B-vonalak vizsgálatának létjogosultságát támasztják alá azok a kutatási eredmények, ahol szoros összefüggést találtak a B-vonalak száma valamint a pulmonalis éknyomás között $(5,6)$.

\section{Metódus}

\section{A B-vonalak feltérképezése, a tüdő}

ultrahangvizsgálata a betegágy mellett

Tüdőultrahang során a B-vonalakat legtöbbször a hagyományos kardiológiai vizsgálathoz használt transzducerrel vizsgáljuk, de a hordozható készülékek is megfelelőek. Egyszerü 2D-képalkotást használunk, nem szükséges felharmonikus képalkotás, illetve Doppler-

\begin{tabular}{|c|c|c|c|c|c|c|c|c|}
\hline \multicolumn{2}{|c|}{ Bal oldal } \\
\hline $\begin{array}{c}\text { Középsö } \\
\text { axilláris }\end{array}$ & $\begin{array}{c}\text { Elülsö } \\
\text { axilláris }\end{array}$ & $\begin{array}{c}\text { Midklavi- } \\
\text { kuláris }\end{array}$ & $\begin{array}{c}\text { Para- } \\
\text { sternális }\end{array}$ & Bordaköz & $\begin{array}{c}\text { Para- } \\
\text { sternális }\end{array}$ & $\begin{array}{c}\text { Mdklavi- } \\
\text { kuláris }\end{array}$ & $\begin{array}{c}\text { Elülsö } \\
\text { axillánis }\end{array}$ & $\begin{array}{c}\text { Középsö } \\
\text { axilláris }\end{array}$ \\
\hline & & & & 2 & & & & \\
\hline & & & & 3 & & & & \\
\hline & & & & 4 & & & & \\
\hline & & & 5 & & & & \\
\hline
\end{tabular}

3. ÁBRA. A B-vonalak vizsgálata az elülső mellkasfalon, 28 meghatározott bordaközben (2)
1. TÁBLÁZAT. A B-vonalak száma és a pulmonalis pangás mértéke közötti összefüggés (7)

\begin{tabular}{|l|l|}
\hline B-vonalak száma & $\begin{array}{l}\text { Extravaszkuláris } \\
\text { folyadék-felszaporodás }\end{array}$ \\
\hline$\leq 5$ & Nincs pangás \\
\hline $6-15$ & Enyhe \\
\hline $16-30$ & Közepes \\
\hline$>30$ & Jelentős \\
\hline
\end{tabular}

metódus. A beteget háton fekvő, vagy félig ülő helyzetben vizsgáljuk. A mellkas elülső és laterális részét, jobb és bal oldalon, a parasternalis, midclavicularis, elülső és középső axilláris vonalban vizsgáljuk, jobb oldalon a másodiktól az ötödik, bal oldalon a másodiktól a negyedik bordaközig (3. ábra).

$A z$ elülső és laterális mellkasfalon, a bordaközökben észlelt B-vonalak számát összeadjuk, így kvantitatív mérést végzünk. A B-vonalak száma a tüdőben található extravaszkuláris folyadékfelszaporodással szoros összefüggést mutat, amely összefüggést az 1. táblázat szemlélteti (7).

Egészséges egyéneknél, ahol nincs pangás, a B-vonalak összesített száma 5 alatt van. Az 1. táblázat következtetései elsőként egy hordozható echokardiográffal történő B-vonal vizsgálatsorozat radiológiailag validált módszerrel való összevetése során alakultak ki. A 121 betegen végzett mellkasfal ultrahangvizsgálat során kapott B-vonalak (amelyeket akkor még „comet-tail” artefaktumnak neveztek) betegenként összesített száma szoros korrelációt mutatott egy radiológiai pontrendszerrel, amelyet az extravaszkuláris tüdővíz-tartalom megítélésére fejlesztettek ki (2). A 4. ábrán szemléltetjük a gyakorlatban egy dyspnoes, balszívfél-elégtelenség tüneteit mutató beteg mellkas ultrahangvizsgálat során detektált B-vonalak számát. Jobb oldalon a B-vonalak összesített száma 17 , bal oldalon pedig 12 , amely közepes mértékű kisvérköri pangásra utal.

A B-vonalak ultrahangvizsgálata már az első kísérletektől kezdve nagyon egyszerünek bizonyult. Echokardiográfiában nem jártas orvos is képes néhány pozitív vizsgálat után önállóan megítélni a beteg extravaszkuláris tüdővíztartalmát, így a fizikális vizsgálattal, illetve konvencionális mellkasröntgen során nem vagy nehezen megítélhető interstitialis ödéma is felismerésre kerülhet. Egyetlen gyakorlati tanács, hogy a transzducert a pleura vonalára merőlegesen érdemes tartani. Az ultrahang beállítása nem kíván speciális jártasságot. A beteg testalkatának megfelelően állítandó a mélység, amely során a pleura jó láthatósága az elsődleges szempont. Megfigyeléseink alapján sem a felharmonikus üzemmód, sem a magas frekvenciájú, esetleg nagyobb transzducerek esetében nem változik a B-vonalak száma, bár az utóbbi transzducer specifikációkkal kissé jobb a vizuális élmény. 


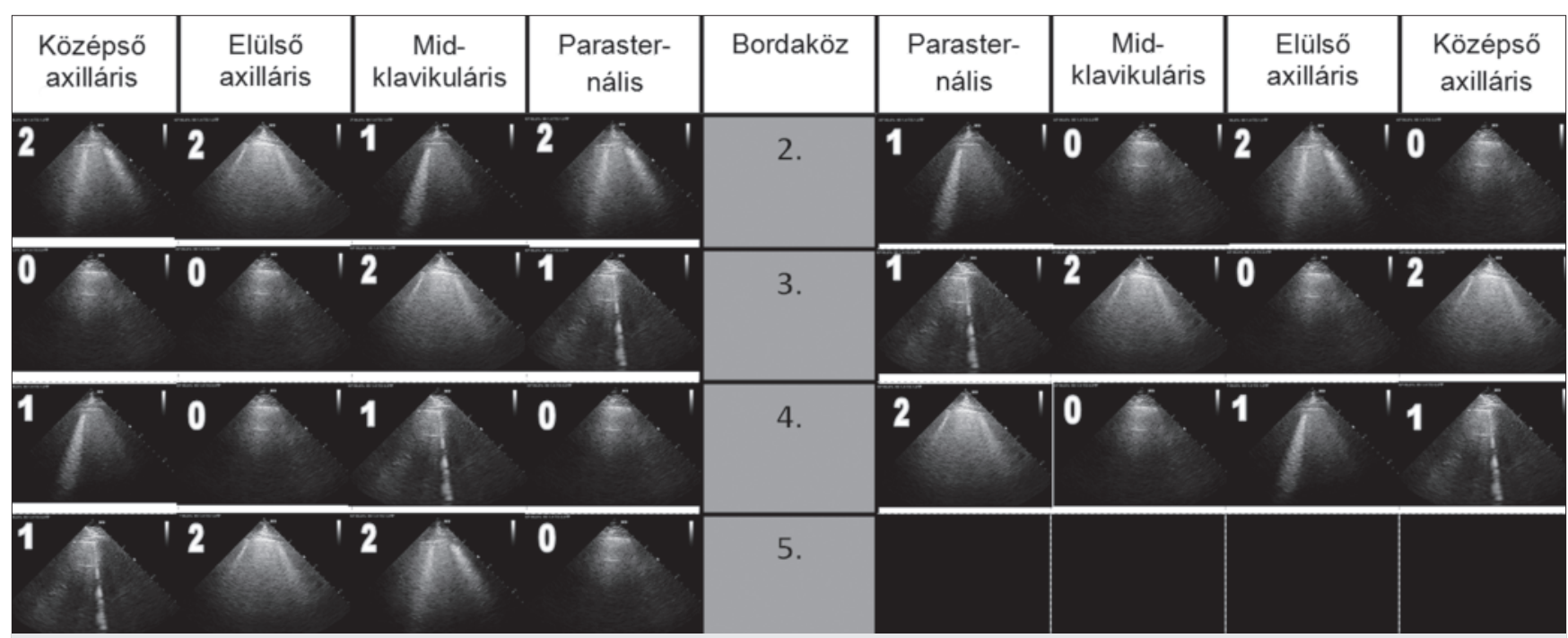

4. ÁBRA. Balszívfél-elégtelenség tüneteit mutató, légszomjra panaszkodó beteg mellkasi ultrahangvizsgálata. Jobb oldalon a B-vonalak összesített pontszáma 17, bal oldalon pedig 12, mely közepes mértékú kisvérköri pangásra utal

\section{Ultrahangos B-vonalak experimentális tüdőödéma esetén}

A Szegedi Tudományegyetemen végzett állatkísérlet során az altatott, lélegeztetett vietnámi csüngőhasú malacokban oleinsavval létrehozott kísérletes tüdőödéma alatt végzett mellkasi ultrahangvizsgálat eredménye jó korrelációt mutatott a tüdőszövet valós víztartalmával. A tüdő víztartalmát az ultrahangvizsgálat után közvetlenül leölt állatok tüdőszövetének gravimetriás vizsgálatával határoztuk meg, amely végeredményben a szövet száraz/nedves tömegének arányával jellemezhető (8). A vizsgálat jelentősége, hogy a tüdő víztartalmának direkt meghatározásához hasonlítottuk a noninvazív vizsgálat eredményét.

\section{A B-vonalak gyakorlati jelentősége szívelégtelenséglben}

Sürgősségi körülmények között a B-vonalak vizsgálata alkalmas az akut dyspnoés beteg differenciáldiagnosztikájára. Fulladós, hypoxiás, hemodinamikailag instabil, nehezen mozgatható betegek esetén a kardiális eredetű légszomjat magas szenzitivitással és specificitással képes elkülöníteni a fulladás egyéb etiológiai tényezőitől (9). Multicentrikus, prospektív vizsgálatok alapján a B-vonalak vizsgálata a heveny dyspnoe eredetének megállapításában magasabb szenzitivitással és specificitással rendelkezik, mint a fizikális vizsgálat, a mellkasröntgen-vizsgálat vagy a nátriuretikus peptid meghatározás (10). Krónikus szívelégtelen betegek ambuláns gondozása és követése során, a vizitek alkalmával feltérképezett B-vonalak száma szoros összefüggést mutatott a későbbi állapotrosszabbodással, az ismételt hospitalizációval, illetve a mortalitással. Azok a szívelégtelen betegek, akiknél az ambuláns vizitek alkalmával több B-vonalat detektáltak, az utánkövetési periódusban négyszer nagyobb eséllyel kerültek szí- velégtelenség miatt kórházba és négyszer nagyobbak voltak a mortalitási mutatóik is, szemben azokkal a betegekkel, ahol nem lehetett B-vonalat detektálni, illetve kevés B-vonalat láttak (11). Az ambuláns betegek gondozásán kívül a szívelégtelen betegek hazabocsátása előtt is érdemes a B-vonalak számát felmérni, ugyanis a B-vonalak száma az elbocsátáskor erős prediktora az ismételt hospitalizációnak, állapotrosszabbodásnak és mortalitásnak (12). Azok a betegek, akiknél kevés B-vonalat számlálunk, illetve nem látunk B-vonalat, kifejezetten alacsony rizikóval rendelkeznek a szívelégtelenség progressziója és a hospitalizáció tekintetében (13). Akut koronária szindróma esetén a GRACE-rizikó és mortalitási skála meghatározásával párhuzamosan, a bal és jobb kamra diasztolés és szisztolés funkció, valamint a B-vonalak feltérképezése szintén prognosztikus jelentőséggel bír (14).

A tüdő ultrahangvizsgálata, a B-vonalak számának megállapítása a szívelégtelenség-terápia effektivitásának monitorozására is alkalmas, így a terápiás döntéseket, a beteg állapotát követni lehet. Manifesztálódott szívelégtelenségben alkalmazott diuretikus terápiát követően a B-vonalak száma jelentősen csökken, a beteg panaszainak enyhülésével párhuzamosan $(2,15)$. Ugyancsak megfigyelhető a B-vonalak csökkenése krónikus veseelégtelen betegek hemodialízisét követően (16).

Nem publikált, azonban az ESC kongresszusán bemutatott megfigyelésünk szerint a módszer alkalmas kritikus állapotú, lélegeztetett, keringéstámogató (gyógyszeres, illetve intraaortikus ballonpumpa) kezelésben részesülő betegek extravaszkuláris tüdővíz-tartalmának meghatározására, amely nagy segítség lehet a terápiás döntésekben. Az ultrahangos mellkasvizsgálat minden betegnél elvégezhető volt és szoros korrelációt mutatott a semiinvazív, termodilúciós elven működő PiCCO2-rendszer által meghatározott értékkel (17). 


\section{A vizsgálat korlátai}

Természetesen a B-vonalak vizsgálatának is vannak korlátai a klinikai gyakorlatban. A tüdőben kialakuló fibrosis a szívelégtelenséghez hasonlóan B-vonalakat eredményez, így a tüdőfibrosisban, szilikózisban kialakuló pangás vizsgálatára nem alkalmas a tüdő ultrahangozása. Hasonlóan, heveny respiratorikus distressz-szindrómában sem használtható teljes biztonsággal az eljárás, ugyanis itt jelentős számú, konfluáló B-vonal látható, echodenz, fragmentált pleurával. Fontos megemlíteni, hogy COPD-s betegek esetében viszont hasznos eljárásnak bizonyul, mivel COPD talaján kialakult légszomj esetén nem láthatóak B-vonalak. A fenti kórképek diagnosztizálásához egyéb képalkotó vizsgálat szükségesek. Szükség esetén a B-vonalak pangásos etiológiájának tisztázásában a transthoracalis szívultrahang-vizsgálat segít. A bal kamra szisztolés és diasztolés funkciója, a szignifikáns vitiumok jelenléte, az emelkedett pulmonalis nyomás, vagy a vena cava inferior átmérője és kollapszusa segít a pangás kardiológiai okának elkülönítésében.

\section{Jelenleg érvényben lévő ajánlások a mellkas ultrahangvizsgálatra}

A mellkas UH-vizsgálata az ESC 2010-es állásfoglalása alapján egy potenciálisan hasznos eszköz a pulmonalis pangás vizsgálatára (18). 2015 óta javasolt első vonalbeli vizsgálómódszer akut szívelégtelenség esetén a tüdőpangás megítélésére (19). Megállapíthatjuk, hogy tapasztalt kézben, a hagyományos mellkasröntgen-vizsgálattal minimum azonos informatív értékkel bír, míg hozzáférhetősége, költsége kedvezőbb. Szívelégtelen betegnél a kezelés sikerességének megítélése céljából a 2012-ben tett nemzetközi ajánlás ideális választásnak tartotta (20). Ugyancsak megemlítendő, hogy a mostanában elterjedőben lévő hordozható (vagy zseb-) ultrahangkészülékek számára az egyik legfontosabb felhasználási terület lehet. A 2016-os EACVI ajánlás hasznosnak tartja a pulmonális pangás megítélésére terheléses echokardiográfia során jelentkező dyspnoeban (21).

\section{Következtetések}

A pulmonalis pangás meghatározó patofiziológiai jelenség szívelégtelenségben. A tüdőparenchymában lévő folyadékfelszaporodás kimutatása akut és krónikus (szubklinikus) szívelégtelenségben nemcsak a diagnózis felállításában, hanem a terápiás lépések vezetésében, a prognózis felállításában is alapvető jelentőséggel bír. A tüdő szövete szívelégtelenségben a légtartalom-csökkenés és a folyadékfelszaporodás következtében ultrahanggal vizsgálhatóvá válik és a pangás B-vonalak képében manifesztálódik. A B-vonalak a pleura felszínéből kiinduló üstökösszerű, vertikális nyalábok. Kvantitatív és szemikvantitatív vizsgálatuk a diagnózis felállításában, a terápiás lépéseinkre adott válasz megítélésében is segít, és a prognózis meghatározásában is hasznos. Rendkívül könnyen elsajátítható, rövid ideig tartó, ágy melletti, korlátlanul ismételhető, sugárzásmentes vizsgálóeljárásról van szó, amely kiemelt jelentőséggel bír a szívelégtelen betegek gondozásában.

\section{Irodalom}

1. Lichtenstein $D$, et al. The comet-tail artifact. An ultrasound sign of alveolar-interstitial syndrome. American journal of respiratory and critical care medicine 1997; 156: 1640-6.

https://doi.org/10.1164/ajrccm.156.5.96-07096

2. Jambrik Z, et al. Usefulness of ultrasound lung comets as a nonradiologic sign of extravascular lung water. The American Journal of Cardiology 2004; 93: 1265-70.

https://doi.org/10.1016/j.amjcard.2004.02.012

3. Soldati G, et al. Ex vivo lung sonography: morphologic-ultrasound relationship. Ultrasound in medicine \& biology 2012; 38: 1169-79.

https://doi.org/10.1016/j.ultrasmedbio.2012.03.001

4. Spinelli $A$, et al. Realization of a poro-elastic ultrasound replica of pulmonary tissue. Biomatter 2012; 2: 37-42

https://doi.org/10.4161/biom.19835

5. Agricola E, et al. "Ultrasound comet-tail images": a marker of pulmonary edema: a comparative study with wedge pressure and extravascular lung water. Chest 2005; 127: 1690-5.

https://doi.org/10.1378/chest.127.5.1690

6. Frassi $F$, et al. Prognostic value of extravascular lung water assessed with ultrasound lung comets by chest sonography in patients with dyspnea and/or chest pain. Journal of cardiac failure 2007; 13: 830-5. https://doi.org/10.1016/j.cardfail.2007.07.003

7. Picano $E$, et al. Ultrasound of extravascular lung water: a new standard for pulmonary congestion. European heart journal 2016; 37: 2097-104. https://doi.org/10.1093/eurheartj/ehw164

8. Jambrik Z, et al. B-lines quantify the lung water content: a lung ultrasound versus lung gravimetry study in acute lung injury. Ultrasound in medicine \& biology 2010; 36: 2004-10.

https://doi.org/10.1016/j.ultrasmedbio.2010.09.003

9. Al Deeb M, et al. Point-of-care ultrasonography for the diagnosis of acute cardiogenic pulmonary edema in patients presenting with acute dyspnea: a systematic review and meta-analysis. Academic emergency medicine: official journal of the Society for Academic Emergency Medicine 2014; 21: 843-52.

https://doi.org/10.1111/acem.12435

10. Pivetta E, et al. Lung Ultrasound-Implemented Diagnosis of Acute Decompensated Heart Failure in the ED: A SIMEU Multicenter Study. Chest 2015; 148: 202-10. https://doi.org/10.1378/chest.14-2608

11. Platz E, et al. Detection and prognostic value of pulmonary congestion by lung ultrasound in ambulatory heart failure patients. European heart journal 2016; 37: 1244-51.

https://doi.org/10.1093/eurheartj/ehv745

12. Coiro $S$, et al. Prognostic value of residual pulmonary congestion at discharge assessed by lung ultrasound imaging in heart failure. European journal of heart failure 2015; 17: 1172-81.

https://doi.org/10.1093/eurheartj/ehv745

13. Gargani L, et al. Persistent pulmonary congestion before discharge predicts rehospitalization in heart failure: a lung ultrasound study. Cardiovascular ultrasound 2015; 13: 40.

https://doi.org/10.1186/s12947-015-0033-4

14. Bedetti G, et al. Comparison of prognostic value of echographic [corrected] risk score with the Thrombolysis in Myocardial Infarction (TIMI) and Global Registry in Acute Coronary Events (GRACE) risk scores in acute coronary syndrome. The American journal of cardiology 2010; 106: 1709-16. 
https://doi.org/10.1016/j.amjcard.2010.08.024

15. Facchini $C$, et al. Lung ultrasound and transthoracic impedance for noninvasive evaluation of pulmonary congestion in heart failure. Journal of cardiovascular medicine 2016; 17: 510-7.

https://doi.org/10.2459/JCM.0000000000000226

16. Zoccali C, et al. Pulmonary congestion predicts cardiac events and mortality in ESRD. Journal of the American Society of Nephrology: JASN 2013; 24: 639-46.

https://doi.org/10.1681/ASN.2012100990

17. Jambrik Z, et al. Ultrasound comets: a useful noninvasive method for estimation of extravascular lung water inpatients with cardiogenic shock. European Heart Journal 2010; (2010) 3 (Abstract Supplement): $617-618$.

18. Gheorghiade $\mathrm{M}$, et al. Assessing and grading congestion in acute heart failure: a scientific statement from the acute heart failure committee of the heart failure association of the European Society of Cardiology and endorsed by the European Society of Intensive Care Medicine. European journal of heart failure 2010; 12: 423-33. https://doi.org/10.1093/eurjhf/hfq045

19. Lancellotti $P$, et al. The use of echocardiography in acute cardiovascular care: recommendations of the European Association of Cardiovascular Imaging and the Acute Cardiovascular Care Association. European heart journal cardiovascular Imaging 2015; 16 : 119-46. https://doi.org/10.1093/ehjci/jeu210

20. Volpicelli G, et al. International evidence-based recommendations for point-of-care lung ultrasound. Intensive care medicine 2012; 38: 577-91. https://doi.org/10.1007/s00134-012-2513-4

21. Lancellotti $P$, et al. The clinical use of stress echocardiography in non-ischaemic heart disease: recommendations from the European Association of Cardiovascular Imaging and the American Society of Echocardiography. European heart journal cardiovascular Imaging 2016; 17: 1191-1229. https://doi.org/10.1093/ehjci/jew190 